HOMOSEXUALITY IN COLD WAR AMERICA

NEW AMERICANISTS A Series Edited by Donald E. Pease 
HOMOSEXUALITY 


\section{IN COLD WAR AMERICA}

Resistance and the Crisis of Masculinity

Robert J. Corber

Duke University Press Durham E London

1997 
(C) 1997 Duke University Press

All rights reserved Printed in the United States of America on acid-free paper $\infty$ Typeset in Berkeley Medium with Monotype Twentieth Century display by Keystone Typesetting, Inc. Library of Congress Cataloging-in-Publication Data appear on the last printed page of this book. 
F O R K N T "adhesiveness" 
